ACTA UNIVERSITATIS WRATISLAVIENSIS

No 3780

Studia nad Autorytaryzmem i Totalitaryzmem 39, nr 2

Wrocław 2017

DOI: $10.19195 / 2300-7249.39 .2 .1$

MAŁGORZATA ŁUSZCZYŃSKA

Uniwersytet Marii Curie-Skłodowskiej w Lublinie

ARTUR ŁUSZCZYŃSKI

Uniwersytet Rzeszowski

\title{
Autorytarne prawa naturalne? Kilka uwag o negatywnym potencjale pozytywnych idei
}

Inspiracją do napisania niniejszego artykułu stała się monografia pod redakcją prof. Marii Zmierczak. Książka pt. Prawo natury w doktrynach polityczno-prawnych Europy (Poznań 2006) jest pokłosiem konferencji zorganizowanej przez Panią Profesor w Gnieźnie w 2005 r., jednoczącej środowisko historyków doktryn politycznych i prawnych wokół problematyki prawnonaturalnej.

Uważna lektura poszczególnych części monografii oraz wprowadzenia autorstwa Jana Baszkiewicza nasuwa pytanie nie tylko o istotę praw naturalnych, stosunek prawa natury do praw naturalnych, relacje między prawami naturalnymi a prawem stanowionym, lecz także - a może przede wszystkim - o charakter praw naturalnych. W tym miejscu chcemy zaznaczyć, że ze względu na ograniczenia edytorskie nasze rozważania $\mathrm{w}$ ramach artykułu nie roszczą sobie pretensji do pogłębionego wyjaśnienia wszystkich potencjalnych problemów. Jest to raczej przyczynek do dalszych dyskusji. Nasz wywód czerpać będzie przykłady z różnych epok - starożytności, średniowiecza i czasów nowożytnych — i w większym stopniu zależeć nam będzie na wybraniu pewnych modeli, które naszym zdaniem dobrze ilustrują omawiany problem, niż na zachowaniu ciągłości chronologicznej. $\mathrm{Z}$ powodu rozległości przedmiotowej problematyki swoje rozważania ograniczymy — nawiązując do tytułu monografii pokonferencyjnej — do doktryn polityczno-prawnych Europy.

Problematyka prawnonaturalna jest niezwykle skomplikowana. Wiele niejasności czy wręcz wieloznaczności dotyczących stanowiska prawnonaturalnego jest wynikiem jego złożonego charakteru oraz tego, że zakres zainteresowań niniejszą 
problematyką stanowi przedmiot dociekań interdyscyplinarnych. Wypowiedzi teologów, etyków oraz prawników prezentują rozmaite stanowiska wyznaniowe czy światopoglądowe, a co za tym idzie różne spojrzenia na samo prawo natury, jego źródło, sposób istnienia, kwestię zmienności i charakter ${ }^{1}$. Mimo wielu rozbieżności przedstawiciele poszczególnych dyscyplin naukowych w zasadzie twierdząco odpowiadają na pytanie o istnienie prawa natury. Przez blisko trzy tysiąclecia prawo naturalne funkcjonowało w europejskiej myśli filozoficznej, prawniczej jako jeden ze stałych tematów refleksji natury zarówno prawnej, politycznej, etycznej, jak i społecznej. Mimo licznych zarzutów wysuwanych wobec tej doktryny należy zgodzić się z tezą, że ,zagadnienia prawa naturalnego występują na każdym etapie europejskiej myśli filozoficznej"2. Przyglądając się poszczególnym doktrynom, należy stwierdzić trwałość doktryny prawa naturalnego występującego w różnych formach i odmianach w poszczególnych kulturach i religiach, również pozaeuropejskich, takich jak buddyzm, islam czy hinduizm ${ }^{3}$. Notabene, w islamie koncepcje prawnonaturalne, ze względu na brak czytelnej granicy pomiędzy prawem objawionym a stanowionym, zyskują zupełnie nowy wymiar $\mathrm{w}$ odniesieniu do tradycji europejskich. W świadomości ludzkiej mocno zakorzenione jest przekonanie o istnieniu jakiegoś idealnego, nieskażonego błędem legislatora prawa, które stanowi swoisty miernik ludzkich poczynań (w tym również działalności na polu prawotwórstwa $)^{4}$. Jak stosunkowo nietrudno można wywnioskować z tytułu naszego artykułu, dostrzegamy groźbę w nazbyt łatwym popadaniu w myślową koleinę traktowania praw naturalnych jako zawsze postępowych, dobrych, słusznych, nadrzędnych nad ułomnym z definicji prawem stanowionym itp. Jednocześnie, by nie było wątpliwości, wyraźnie zaznaczmy, że mamy świadomość uzasadnień historycznych, które po procesie norymberskim lub procesach tzw. strzelców muru w praktyczny sposób zakwestionowały zasadność przestrzegania wszelkich norm formalnoprawnych.

${ }^{1} \mathrm{~W}$ niniejszym opracowaniu przyjęto filozoficznoprawną płaszczyznę badawczą, pozostawiając na uboczu perspektywę teoretycznoprawną i odrzucając jednocześnie spojrzenie teologiczne oraz etyczne.

${ }^{2}$ H. Waśkiewicz, Historia teorii prawa naturalnego, „Roczniki Filozoficzne” 2, 1969, s. 69.

3 Por. K. Stachewicz, W poszukiwaniu podstaw moralności. Tomistyczna etyka prawa naturalnego a etyka wartości Dietricha von Hildebranda, Kraków 2001, s. 45. Autor ten wysuwa tezę, iż prawo natury w zakresie jej fundamentalnych instytucji nie jest wytworem typowo chrześcijańskoeuropejskim. Obecność zaś pewnych stałych norm moralnych występuje również u ludów prymitywnych. Koncepcje zbliżone do europejskiej i amerykańskiej myśli prawnonaturalnej występują w tradycji judaizmu, islamizmu, hinduizmu, buddyzmu, lecz także w założeniach wypracowanych na terenie Chin i Afryki. Por. H. Waśkiewicz, Powszechność prawa naturalnego, „Studia Philosophiae Christianae ATK" 1970, nr 6, s. 269-270; A. Kość, Filozoficzne podstawy prawa japońskiego w perspektywie historycznej, Lublin 2001, s. 168-169.

${ }^{4}$ O coraz większej ilości danych zebranych w wyniku badań prowadzonych przez współczesną etnologię i historię kultury, potwierdzających jedność moralnej świadomości o ogólnoludzkim zakresie, pisze T. Ślipko, Problem stabilności prawa naturalnego, [w:] Powrót do prawa ponadustawowego, red. M. Szyszkowska, Warszawa 1992, s. 88. 
Wiele trudności wiąże się z odczytaniem treści mieszczącej się w sformułowaniu „prawa naturalne”. O ile w odniesieniu do prawa natury można posługiwać się liczbą pojedynczą ze względu na stosunkowo wąski zakres tego pojęcia, o tyle w stosunku do praw naturalnych liczba mnoga wskazywać ma na ich ilość i różnorodność, wieloaspektowość ${ }^{5}$. W odniesieniu do praw naturalnych należy wskazać ścisłą korelację między ich charakterem a źródłem pochodzenia. Kolejnym czynnikiem, niejednokrotnie stanowiącym determinant charakteru praw naturalnych, jest zagadnienie genezy władzy zwierzchniej. Problematyka ta implikuje $\mathrm{z}$ kolei zawiły stosunek między prawami naturalnymi a porządkiem prawa stanowionego. Na tle tej mozaiki zagadnień kształtuje się charakter praw naturalnych, które w zależności od uwarunkowań kulturowych mogą stać się autorytarne, a nawet totalitarne.

Współcześnie prawo naturalne bywa określane mianami: prawo natury, słuszność, prawa człowieka, prawo elementarne, prawo transpozytywne, prawo intuicyjne (L. Petrażycki), prawo rozumowe (za racjonalistami XVII i XVII w.), wytyczne życia społecznego i postępowania człowieka, prawo pierwiastkowe, prawo idealne (Ch. Perelman) ${ }^{6}$. Stosunkowo często stawiany jest znak równości między prawem naturalnym a sprawiedliwością. Niewątpliwie istnieje ścisła korelacja między ius a iustitia, aczkolwiek tożsamość pojęciową należy zdecydowanie wykluczyć.

Przywołana terminologia wykazuje ścisłą korelację z pochodzeniem praw naturalnych, których źródłem może być zarówno Bóg, jak i istota człowieka, rozum człowieka, natura ludzka, godność jednostki ludzkiej

${ }^{5}$ Dążąc do metodologicznej czystości — tak właściwej notabene normatywizmowi prawniczemu — należy bliżej się przyjrzeć treści kryjącej się pod pojęciem prawa naturalnego. Szerzej zob. M. Łuszczyńska, A. Łuszczyński, Positivisation of the natural law in the contents of constitutions of European countries, [w:] Positive Law in Contemporary Legal Systems, red. B. Lepieszko, D. Walencik, Brest 2009, s 42-45. Pojęcie „prawo naturalne”, „prawo natury” nie jest prostą wypadkową połączenia słów „prawo” oraz „natura”, „naturalny”. Są to terminy wieloznaczne. Pragnąc w miarę możliwości precyzyjnie ustalić sens pojęcia ,prawo natury”, należałoby wyjść poza granice kultury europejskiej.

6 M. Szyszkowska, Filozofia prawa i filozofia człowieka, Warszawa 1989, s. 30, 67. Autorka proponuje również, aby „rozważania nad prawem natury” zastąpić terminem „rozmyślania nad losem człowieka" (eadem, Dociekania nad prawem natury, czyli o potrzebach człowieka, Warszawa 1972, s. 28).

7 Por. R. Forycki, Kilka uwag o prawie natury, [w:] Powrót do prawa ponadustawowego..., s. 31-37; A.L. Zachariasz, Prawo naturalne jako prawo kultury, [w:] Powrót do prawa ponadustawowego..., s. 74. W literaturze spotkamy się z poglądem, iż źródło prawa natury stanowi cechę charakterystyczną doktryn prawa natury w poszczególnych epokach. Otóż starożytni odwoływali się do porządku świata, średniowiecze - do Boga, nowożytność zaś upatrywała fundament tej idei w naturze, współcześni zaś, nawiązując do św. Tomasza, „odwołują się niejednokrotnie do intuicji, głosu wewnętrznego, czyli tzw. sumienia". Por. W. Urmanowicz, U źródeł nauki o zasięgu prawa naturalnego, „Collectanea Theologica” 26, 1955, nr 4, s. 777-800. 
Dla uchwycenia treści kryjącej się pod pojęciem „prawo naturalne”, a w zasadzie „prawa naturalne”, i w konsekwencji charakteru tego prawa należałoby przyjrzeć się jego korelacji z genezą władzy państwowej. Szukając odpowiedzi na pytanie o autorytarny charakter praw naturalnych, należy bacznie przyjrzeć się powiązaniu prawa $\mathrm{z}$ władzą, w szczególności w odniesieniu do jej pochodzenia. Sposób nabycia władzy ma bowiem fundamentalne znaczenie dla relacji między prawami stanowionymi przez władzę zwierzchnią a prawami naturalnymi, $\mathrm{w}$ konsekwencji determinuje więc istotę praw naturalnych.

W historii doktryn polityczno-prawnych należy za Johnem Kellym wyróżnić „rywalizację dwóch przeciwstawnych koncepcji” - teorii władzy „zstępującej” i „wstępującej”. O ile zgodnie z teorią „wstępującą" władza pochodzi od ludu, który powierza ją wybranemu przez siebie podmiotowi, o tyle teoria „zstępująca" zakłada, że sprawujący władzę zwierzchnią nikomu z ludzi jej nie zawdzięczają. Zauważmy tu, że teoria wstępująca wcale nie musi być teorią świecką, gdyż działania ludu-suwerena w optyce religijnej niekoniecznie będą wyrazem czystej wolności.

Fundamentem kultury europejskiej jest chrześcijaństwo, którego doktryna wyrasta z refleksji ojców i doktorów kościoła. W tym kontekście dominuje „teoria zstępująca” — „chrześcijański wariant tej teorii przypisuje Bogu nadanie tej władzy człowiekowi”; rozpowszechniany był przede wszystkim w dziełach pisarzy wczesnochrześcijańskich, np. św. Augustyna, Seduliusza „Szkota”, Honoriusza z Autun czy Anonima z Yorku9. Tak ujęta geneza władzy wyprowadzana była $\mathrm{z}$ tradycji ewangelicznej, a jej kwintesencję stanowiły słowa zaczerpnięte $\mathrm{z}$ Listu św. Pawła do Rzymian: „Nie ma bowiem władzy, jak tylko od Boga”. Podobnie ideę zwierzchnictwa ujmowali Jan z Salisbury i Tomasz z Akwinu: Bóg jest władcą per se, człowiek zaś swoją władzę sprawuje niejako per participationem ${ }^{10}$. Jest on kreatorem rzeczywistości politycznej w zakresie wyłaniania konkretnej władzy instytucjonalnej ${ }^{11}$. Podmiot sprawujący władzę jest sui generis ziemskim wikariuszem Boga, alter post Deum.

Należy wyraźnie zaznaczyć, iż pochodzenie wszelkiej władzy, a w szczególności zwierzchniej władzy politycznej od Boga, nie jest tożsame z przyznaniem rządzącemu boskich prerogatyw. Władza pochodząca od Boga to władza abstrakcyjnie pojęta. Zasada sformułowana przez św. Pawła nie odnosi się bowiem ani

8 J.M. Kelly, Historia zachodniej teorii prawa, Kraków 2006, s. 113.

9 Por. J. Baszkiewicz, Myśl polityczna wieków średnich, Warszawa 1970, s. 91, 98.

10 Sancti Thomae de Aquino, Suber Epistolam S. Pauli Apostoli ad Romanos, 1021. Tomasz z Akwinu osadził koncepcję władzy w kontekście rozważań filozoficznych. Stanowisko przejęte od Pawła z Tarsu znajduje wsparcie zarówno w Starym Testamencie: „Dzięki mnie królowie panują, słusznie wyrokują urzędnicy. Dzięki mnie rządzą władcy i wielmoże — rzadcy prawowierni” (Prz 8, 15-16), jak i w Nowym Testamencie: „Nie miałbyś żadnej władzy nade Mną, gdyby ci jej nie dano z góry” (J 19, 11).

11 M. Sadowski, Godność człowieka i dobro wspólne w papieskim nauczaniu społecznym, Wrocław 2010, s. 88. 
do konkretnego człowieka czy ściśle określonego rodu, ani też do konkretnej formy ustrojowej. Chodzi o samą istotę władzy. Otrzymanie władzy w drodze nadania jej przez Stwórcę implikuje konieczność postępowania zgodne z wolą bożą, czyli kroczenie drogą wiodącą ku zbawieniu zgodnie z bożymi drogowskazami. Rządzący nie tworzy zatem praw naturalnych, lecz odkrywa je w myśl koncepcji partycypacji w prawie wiecznym ${ }^{12}$. Władza, dzięki nadaniu jej w drodze cesji przez Kreatora ziemskiego ordo, kontynuuje zamysł boży w zakresie ładu społecznego ${ }^{13}$. W ten sposób rządzący, nie będąc odpowiedzialnymi przed poddanymi, są odpowiedzialni za nich (sprawując władzę w ich interesie) ${ }^{14}$.

Istotne znaczenie mają relacje, $\mathrm{w}$ jakie wchodzi prawo $\mathrm{z}$ systemem wartości preferowanych w danej społeczności. Kwestia ta budzi wiele dyskusji, wywołuje emocje i prowadzi do odwiecznego sporu między zwolennikami prawa naturalnego a jego przeciwnikami. Jej rozwiązanie prowadzi bezpośrednio do uformowania ostatecznego charakteru praw stanowionych. Dopóki spory aksjologiczne, koncentrujące się wokół systemu prawa stanowionego, zaznaczają się głównie w poglądach etyków i teologów, nie ma mowy o autorytarnym zabarwieniu praw naturalnych. Charakter „tyrański” zyskiwać będą, wówczas gdy stanowisko o podległości ius positivum prawom naturalnym prezentowane będzie przez prawników, polityków, a w dalszej kolejności przez ustawodawcę.

Problematyka aksjologiczna staje się zatem kamieniem węgielnym autorytaryzmu praw naturalnych oraz zarzewiem sporów wokół treści prawnonaturalnych, wówczas gdy następuje jej ścisłe zespolenie z prawdami wiary, z religią i jej dogmatami. W ten sposób dochodzimy do kolejnego zagadnienia, które samo w sobie staje się problemem na osobną publikację. Chodzi o relacje między prawem stanowionym a prawami naturalnymi. Należy w tym miejscu nadmienić, że w kulturze prawnej Zachodu idee prawnonaturalne wywierają wpływ przede wszystkim na tworzenie prawa, a nie na praktykę jego stosowania.

Wyróżnienie tych dwóch rodzajów praw rozpoczęło trwające od stuleci i niezakończone do dzisiaj spory ${ }^{15}$. Wszelkie dyskusje i polemiki koncentrują się na wyraźnym przeciwstawieniu prawa naturalnego prawu pozytywnemu i próbach wykazania wyższości jednego prawa nad drugim. Są niejednokrotnie wynikiem

12 Św. Izydor z Sewilli, Etymologiae, 9, 3.

13 E.H. Kantorowicz, The King's Two Bodies. A Study in Medieval Political Theory, Princeton 1957, s. 143-192.

14 J.M. Kelly, op. cit., s. 117.

15 Por. J. Wróblewski, Wptyw prawa natury na prawo pozytywne, „ZN UŁ. Nauki Humanistyczno-Społeczne” 1968, nr 1, s. 3-33. Z kolei Lech Falandysz pisze o „odwiecznej konkurencji” dwóch szkół występujących w obrębie filozofii prawa: szkoły myślenia pozytywistycznego i prawa naturalnego: „Uświadomiłem sobie, że filozofia prawa naturalnego jest filozofią buntu, filozofią zmian i że do niej sięgają najczęściej rzecznicy zmian. Paradoksalnie ewolucje, czy wszelkie zmiany, dokonywane w imię prawa naturalnego, sięgają później po pozytywizm. [...] To przerodzenie w pozytywizm wynika z chęci utrzymania władzy" (idem, Likwidacja filozofii prawa, [w:] Nauka a polityka. Dziwne losy filozofii prawa, red. M. Szyszkowska, Warszawa 2001, s. 125-127). 
poszukiwań norm doskonałych, będących „regułą i miarą” prawa stanowionego ${ }^{16}$. W retrospektywnym ujęciu szala zwycięstwa przechylała się raz na jedną, raz na drugą stronę. Śmiało można jednak stwierdzić, że nigdy w ciągu stuleci nie doszło do całkowitej eliminacji jednego z konkurujących z sobą ujęć.

W ramach polemik między apologetami pozytywizmu a zwolennikami praw naturalnych widać ostro zarysowaną różnicę zdań, która uwypukla się na trzech płaszczyznach ${ }^{17}$. Zasadniczą przyczynę sporów stanowi kwestia podejścia do obowiązującego prawa. Opowiadający się za prawem stanowionym podchodzą do powyższego zagadnienia w sposób obiektywny, nie dokonując jego wartościowania, uznają je za quasi-fakt. Zwolennicy odmiennego stanowiska prezentują teorie praw naturalnych, które dokonują oceny i wartościują prawo ujmowane jako lex lata. Owa ocena przeprowadzana jest z punktu widzenia jedynie słusznych, niezmiennych i idealnych praw naturalnych i formułowana jest pod adresem aktów prawa stanowionego jako postulat de lege ferenda. Ponadto należy zaznaczyć, iż konkurujące z sobą koncepcje tworzą odmienne teorie prawa. Prawo pozytywne to nic innego jak reguły stanowione przez właściwy organ państwowy, mające charakter imperatywny i powszechnie obowiązujący, tworzące spójny i zupełny system. Natomiast doktryny praw naturalnych niosą przede wszystkim pewne ideały przyjmujące na siebie kształt wzorów postępowania, których człowiek - dokonując uogólnienia - nie jest twórcą, lecz odkrywcą. $\mathrm{W}$ związku z tym prawo stanowione stoi zdecydowanie niżej w hierarchii systemów prawnych. W tym ujęciu prawa naturalne stają się autorytarne. Trzecią płaszczyznę tworzy ideologizacja praw naturalnych.

Ideologia prawa natury jest ideologią krytyczną wobec prawa obowiązującego, formułuje kryteria jego oceny i przyznaje mu wartość pod warunkiem zgodności jego treści z regułami sprawiedliwymi prawa natury czy też z jego wartościami ${ }^{18}$.

We współczesnych państwach dominuje prawo pozytywne i refleksja nad nim, bez wikłania się w hipotetyczne refleksje nad kwestiami filozoficznoprawnymi. Rozważania nad prawem dotyczą zatem prawa stanowionego - tego, które jest, obowiązuje, a nie de lege ferenda. Niemniej nawet w najbardziej spokojnych czasach dochodzi do dyskursu odwołującego się do norm prawnonaturalnych w odniesieniu do zagadnień o silnym zabarwieniu etycznym, dużym ładunku emocjonalnym. Takim zagadnieniem są dylematy wiązane z początkiem i końcem ludzkiej egzystencji.

16 Biorąc zatem za kryterium stosunek prawa natury do prawa będącego wynikiem działalności legislatora, wyróżnić można za T. Benschem „trzy różne epoki” w dziejach ludzkości. T. Bensch, Ksztaltowanie się poglądów na stosunek prawa naturalnego do pozytywnego, „Prąd” 1937, nr 33, s. $170-176$.

17 Szerzej zob. K. Opałek, J. Wróblewski, Prawo. Metodologia, filozofia, teoria prawa, Warszawa 1991, s. 126-128. Autorzy, dokonując gruntownej specyfikacji, oparli się na pracy N. Bobbio, Giusnaturalismo e positivismo giurdico, Milano 1965, rozdz. 5-13.

18 K. Opałek, J. Wróblewski, op. cit., s. 127. 
Co do tego, że podstawowym prawem naturalnym jest prawo do życia, nie ma wątpliwości. Obiekcje zaczynają się przy ustalaniu momentu, w którym prawa naturalne, a w ślad za nimi stanowione, zaczynają obowiązywać: od poczęcia czy od urodzenia? Odpowiedź na tak postawione pytanie generuje jednocześnie rozwiązanie kwestii dopuszczalności aborcji i prowadzi do kolejnego zagadnienia: końca ludzkiej egzystencji. W dyskusjach o dopuszczalności eutanazji pojawiają się argumentacje, w których istotą jest niejednoznaczna odpowiedź na pytanie: kto może decydować o ludzkim życiu? Nawet gdy pytanie to dotyczy mnie samego. Innymi słowy, czy mamy do czynienia z prawem do życia, czy może obowiązkiem życia?

Prawa naturalne w perspektywie religijnej zyskują jak najbardziej autorytarny charakter, odnosząc się przede wszystkim do początku i końca ludzkiej egzystencji, a co za tym idzie wkraczając na grunt kształtowania poszczególnych idei doniosłych dla życia społecznego. Ogólnie ujęte prawo do życia prowadzi do wielu dylematów w wypadku uszczegóławiania tego prawa, np. w odniesieniu do zakazu palenia tytoniu w miejscach publicznych. Z kolei interpretacje podstawowego prawa naturalnego prowadzą do wielu dylematów i dyskusji, np. w odniesieniu do idei wolności.

Kwestia wolności w perspektywie doktryny Kościoła katolickiego jawi się przede wszystkim jako wolność od grzechu. Wolność nie jest jednak swobodą w wyborze stylu i sposobu życia. Powołując się na autorytet praw naturalnych w ujęciu religijnym, ich zwolennicy postulują np. ograniczanie prawa do wypowiedzi, wolności pracy w imię ochrony uczuć religijnych, a nawet własności w imię solidarności i idei subsydiarności. Autorytet praw naturalnych każe stanąć także w opozycji do związków partnerskich.

W ujęciu retrospektywnym, już od czasów stoików, idee prawnonaturalne miały być swoistą matrycą prawa stanowionego, wzorem możliwym do urzeczywistnienia. Prawa naturalne przedstawiają się jako „metaprawo”, „superprawo”, stając się dzięki temu swoistym miernikiem, punktem odniesienia, a dla wielu wręcz wyrocznią prawa stanowionego. Prawa te jawią się jako pewien ład, harmonia, coś, co wprowadza porządek i reguluje zachowania człowieka. Trzeba jednak wziąć pod uwagę, że na formułowanie poszczególnych teorii prawa natury ogromny wpływ miały realia życia społecznego, politycznego oraz w pewnym stopniu gospodarczego. Są więc wypadkową tła historycznego warunkującego ich powstanie oraz reakcji na wcześniejsze teorie czy rozwiązania preferowane przez systemy filozoficzne poprzedniej epoki ${ }^{19}$. Wbrew pozorom dyskusja na ten temat nie jest sporem czysto akademickim i w związku z tym nie powinna ograniczać się wyłącznie do forum uczelni. Bez większej trudności można wskazać prawa tworzone przez legalną władzę, a zawierające zbrodnicze treści.

19 Tezę o niemożności stworzenia jednej teorii prawa natury, uzasadnianą wielością systemów prawa natury, stawia D. Tanalski, Wartości konstytucji i konkordatu, [w:] Powrót do prawa ponadustawowego..., s. 121. 
Inny przykład stanowią spory i polemiki, które rozgorzały wokół Konstytucji RP z 1997 r. Większość tych, mniej lub bardziej ostrych, dyskusji koncentrowała się wokół zagadnień prawa naturalnego, odnosząc się przede wszystkim do kształtu preambuły oraz „,systemu źródeł prawa oraz wolności, prawa i obowiązków człowieka i obywatela" 20 .

Kwestią, która poróżniła środowisko prawnicze, jest problematyka aksjologiczna dotycząca roli i miejsca wartości w prawie. Dokładniej rzecz ujmując, chodzi o odpowiedź na pytanie: czy można uzasadniać obowiązywanie prawa bez odwoływania się do podstawowych wartości? Powyższa kwestia nasunęła kolejną wątpliwość, a mianowicie: czy można uznać za prawo zasady zapisane przez ustawodawcę w postaci aktów prawnych wydanych przez właściwe gremium, we właściwy sposób i we właściwym czasie, ale nierespektujące fundamentalnych ludzkich wartości? Na tak sformułowane pytanie należy udzielić odpowiedzi negatywnej. Ogół starań skupiających się wokół znalezienia zasad mogących stać się wzorem i miarą prawa pozytywnego czyniony jest z reguły z pozycji prawa naturalnego.

Do „odrodzenia” doktryn prawnonaturalnych dochodzi, co do zasady, przy okazji poszukiwania jakiejś zobiektywizowanej miary poczynań jednostki ludzkiej, dobra i zła, sprawiedliwości i niesprawiedliwości. Stają się one wówczas „konstruktem teoretycznej refleksji, postulatem teoretycznego myślenia, poszukującego obiektywnych podstaw dla ludzkiej moralności i prawa stanowionego"21. Doktryna ta stanowi niejednokrotnie podwaliny programów politycznych,

20 P. Winczorek, Problem prawa naturalnego $w$ dyskusjach konstytucyjnych, [w:] Powrót do prawa ponadustawowego..., s. 131 (projekty odwołań do prawa naturalnego oraz stanowiska poszczególnych ugrupowań politycznych zostały przedstawione na s. 131-134). Por. L. Morawski, Spór o pojęcie państwa prawnego, „Państwo i Prawo” 1994, nr 7-8, s. 3-12; K. Działocha, W. Gromski, Niepozytywistyczna koncepcja państwa prawnego a Trybunat konstytucyjny, „Państwo i Prawo" 1995, nr 3, s. 4-16; A. Zoll, Związanie sędziego ustawa, [w:] Konstytucja i gwarancje jej przestrzegania. Księga pamiątkowa ku czci prof. Janiny Zakrzewskiej, red. J. Trzciński, A. Jankiewicz, Warszawa 1996, s. 246; H. Roth, W sprawie koncepcji prawa i praworzadności, „Państwo i Prawo" 1994, nr 7-8, s. 109-111. Problematyka prawa naturalnego na trwałe zagościła zatem w literaturze z zakresu prawa konstytucyjnego, np. W. Skrzydło, Konstytucja Rzeczypospolitej Polskiej. Komentarz, Kraków 2000, s. 42-43. Por. także R. Małajny, Regulacja kwestii konfesyjnych w Konstytucji III RP (refleksje krytyczne), [w:] Ze sztandarem prawa przez świat, red. R. Tokarczyk, K. Motyka, Kraków 2002, s. 277-306; M. Stefaniuk, Obowiązki człowieka i obywatela w projektach Konstytucji RP z dnia 2 kwietnia 1997 r. na tle polskich konstytucji ustrojowych $w$ XX w, [w:] Ze sztandarem prawa przez świat..., s. 351-379.

21 K. Stachewicz, op. cit., 49. Należy jednak pamiętać, że posługiwanie się prawem natury może rodzić poważne niebezpieczeństwo nadużywania tego terminu. Pogląd, iż prawo naturalne wyraża jedynie postępowe działania w duchu korekty zastanego porządku prawnego, jest jak najbardziej błędny. Historii znane są poczynania podejmowane $\mathrm{w}$ imię prawa natury do osiągnięcia wstecznych celów i przebrzmiałych koncepcji. 
społeczno-ekonomicznych tworzonych i wykorzystywanych w różnych celach i przy rozmaitych okazjach ${ }^{22}$.

Spojrzenie na pochodzenie prawa natury jest ściśle skorelowane ze sposobem jego rozumienia ${ }^{23}$. Teorie wskazujące na istotę człowieka jako źródło prawa natury głoszą, że prawo to istnieje w sposób jak najbardziej obiektywny, tj. niezależnie od ludzkiej woli, a nawet świadomości. Teorie odwołujące się do ludzkiego rozumu głoszą również programowy obiektywizm. Natomiast zwolennicy poglądu, iż prawo natury ma swoje źródło w ludzkiej naturze, konsekwentnie podtrzymują tezę o zależności między bytem prawa a istnieniem człowieka. Poglądy optujące za nawiązaniem do godności człowieka podkreślają z kolei jej nadprzyrodzony charakter oraz stworzenie człowieka na podobieństwo Boga. W ten sposób następuje religijne uzasadnienie godności człowieka, a tym samym ma miejsce zbliżenie do teorii uznających Boga za stwórcę jednostki ludzkiej i kreatora prawa naturalnego. Na podkreślenie zasługuje, że owa godność nie zostaje bliżej sprecyzowana ani w żaden sposób dookreślona.

Wszystkie te teorie mają jednak wspólny mianownik. Mimo różnic w podejściu do istoty prawa natury oraz odmiennego ujęcia jego genezy uznają to prawo za kwintesencję aksjologii, uzasadnienie każdego działania czy zaniechania już podjętego w obronie człowieka oraz w obronie wartości przez niego wyznawanych. Współcześnie wiele teorii — zwłaszcza na gruncie nauki katolickiej — wywodzi prawo natury z godności człowieka ${ }^{24}$. To ujęcie prezentowane jest w wielu pracach polskich myślicieli. Wyraźnie ten punkt widzenia prezentuje Eugeniusz Jarra, który pod pojęciem ,godność człowieka” rozumie zespół cech i właściwości moralnych stanowiących jego bezwzględną, wewnętrzną wartość, niezależną

22 Poszczególne programy polityczne, socjalne czy ekonomiczne, powołując się na prawa człowieka, odnoszą się — chcąc czy nie chcąc — do prawa naturalnego. Oczywiście konkretne ujęcie tych praw zależeć będzie od zindywidualizowanego podejścia filozoficznego, religijnego bądź ideologiczno-politycznego.

${ }^{23}$ Kontrowersyjne wydają się poszukiwania Marii Szyszkowskiej prawa natury w tych doktrynach, które nie tyle nawet odżegnują się, ile otwarcie i wyraźnie krytykują prawo natury. M. Szyszkowska uważa, że w każdym systemie filozoficznym, nawet zajadle zwalczającym prawo ponadustawowe, można wyśledzić istnienie prawa natury. Twierdzi, że wszelkie spory są tylko sporami o nazwę, a „stanowiska uczestników sporu zdeterminowane tym, co podkładają pod pojęcie prawa natury" (eadem, Filozofia prawa i filozofia..., s. 79-89). Z powyższymi wywodami nie można się zgodzić bezkrytycznie. Momentami są to zbyt daleko idące wnioski, zbyt duże uogólnienia. Prawa natury autorka dopatruje się bowiem m.in. w doktrynie Marksa, Kelsena, solidaryzmie czy egzystencjalizmie. W kwestii solidaryzmu interesującą tezę stawia Jerzy Kalinowski, zdaniem którego Duguit stworzył „system pozytywny prawa naturalnego”. W owym systemie odpowiednikiem prawa naturalnego jest reguła społeczna. Zob. J. Kalinowski, Teoria reguły społecznej i reguly prawnej Leona Duguita, Lublin 1949.

24 Por. M. Sadowski, Ze studiów nad papieska koncepcja godności człowieka (1981-1991), [w:] Doktryny polityczne i prawne u progu XXI wieku, red. M. Maciejewski, M. Marszał, Wrocław 2002, s. 407-423; S. Wyszyński, Co duszpasterz może zrobić dla urzeczywistnienia ustroju korporacyjnego, [w:] A. Roszkowski, Korporacjonizm, Lublin 1939, s. 255. 
od czasu i przestrzeni ${ }^{25}$. Z tego źródła wypływają prawa człowieka, które są w tej doktrynie tożsame z prawem natury ${ }^{26}$.

Jest tedy godność i prawo człowieka puklerzem przeciwko omnipotencji państwa; jest podstawą do przełamania jego wszechwładzy przez wyodrębnienie z Cesarskiego - Boskiego ${ }^{27}$.

Pozwala to na wyłączenie określonej grupy wartości podstawowych z kręgu zagadnień zależnych od jakichkolwiek decyzji o charakterze władczym, nawet gdy podejmowane są na forum publicznym, w drodze głosowania. Swoistym skrótem myślowym będzie twierdzenie o prawie natury jako ostoi wyznawanych wartości, możliwości przezwyciężania poczucia bezradności jednostek wobec prawa pozytywnego. Stąd tak częste są odwołania do prawa ponadustawowego w wypadku kryzysów politycznych lub moralnych, wojen, katastrof czy innych kataklizmów, gdy wzmaga się społeczne odczuwanie prawa pisanego jako niesprawiedliwego, a więc krzywdzącego, odległego od postulatu słuszności ${ }^{28}$. Prawo natury stoi zatem na straży godności, wolności i systemu wartości przynależnych jednostce ludzkiej. Można więc mówić o cykliczności wzmożonego zainteresowania prawem naturalnym, które stanowi niepodważalny argument na rzecz uniwersalności tego prawa ${ }^{29}$. Trudno nie podzielać stanowiska prezentowanego przez Marię Borucką-Arctową, która pisze:

Koncepcja prawa natury nie jest konstrukcją, którą można by wiązać z myślicielami pewnej określonej epoki. [...] Jest wyrazem poszukiwania pewnych absolutnych ideałów, które mogłyby stać się uzasadnieniem aspiracji i dążeń określonych pokoleń, bądź pomóc w przeciwstawieniu się wadom i niesprawiedliwości istniejących stosunków i obowiązujących zasad postępowania $^{30}$.

Należy jednak podkreślić, że prawo naturalne to nie tylko zespół podstawowych uprawnień człowieka, lecz także pewien wachlarz obowiązków, które określają zakres działań oraz zaniechań uniemożliwiających występowanie przeciw sobie, społeczności lokalnej oraz ludzkości jako takiej (czyli najwyższej formie bezprawności).

25 E. Jarra, Człowiek a władza, Londyn 1948, s. 1.

${ }^{26}$ M. Borucka-Arctowa słusznie zauważa, że koncepcja praw człowieka kształtowała się w ścisłym związku z teorią prawa natury. Por. eadem, Współczesna koncepcja praw człowieka, [w:] Księga pamiątkowa ku czci Konstantego Grzybowskiego, Kraków 1971, s. 53.

27 E. Jarra, op. cit., s. 46.

${ }^{28} \mathrm{O}$ zainteresowaniu problematyką aksjologiczną prawa w okresach transformacji zob. A. Pieniążek, Polityka tworzenia prawa $w$ okresie przemian polityczno-ustrojowych, [w:] $W$ kręgu problematyki władzy, państwa i prawa, red. J. Malarczyk, Lublin 1996, s. 247.

29 O „cyklicznym powrocie praw natury” w kontekście refleksji historiozoficznych związanych z prawem norymberskim zob. M. Zmierczak, Pozytywizm prawniczy a prawnicy i prawo $w$ Trzeciej Rzeszy — powojenna dyskusja niemieckich historyków i teoretyków prawa o przyczynach upadku prawa w czasach nazizmu, „Studia nad Faszyzmem i Zbrodniami Hitlerowskimi” 24, 2001, s. 29.

30 M. Borucka-Arctowa, Prawo natury jako ideologia antyfeudalna, Warszawa 1957, s. 5. 
Tak ujęte prawa naturalne miały być — w założeniu ich twórców - puklerzem przeciw omnipotencji państwa, tarczą ochronną przed tyranem depczącym ideę bonum commune. $\mathrm{Z}$ tego względu miały być stałe, trwałe i niezmienne $\mathrm{w}$ czasie oraz przestrzeni. Takie stoickie pojmowanie praw naturalnych z czasem zaczęło przybierać nowe szaty. Ewolucja praw naturalnych o niezachwianej treści doprowadziła do skostnienia tej teorii, której constans przybrało kształt skorupy uniemożliwiającej rozwój. Z czasem prawa, które miały chronić przed despocją i samowolą władzy, same zaczęły wyrastać na tyrana. Powołując się na autorytet źródła swojego pochodzenia, zaczęły przybierać postać prawa apriorycznego, apodyktycznego i aroganckiego ${ }^{31}$. Prawa naturalne przez narzucenie treści prawu stanowionemu przekreśliły jego autonomię. Mianowicie w doktrynie Kościoła katolickiego prawo stanowione musi wykazywać się — nawiązując do koncepcji psychologicznych — „osobowość autorytarną”. Podmiot uprawniony do stanowienia prawa winien jest gorliwe posłuszeństwo wobec norm prawnonaturalnych stojących wyżej w hierarchii ${ }^{32}$.

Ten swoisty horror iuris naturae ${ }^{33}$ związany jest $\mathrm{z}$ instrumentalizacją prawa oraz chęcią ścisłego powiązania polityki z moralnością, a w szczególności z wizją rozwiązań dylematów etycznych przez podmiot dzierżący ster władzy. W skrajnych przypadkach tak ujmowane prawa naturalne mogą stać się ideologią, a co za tym idzie zmienić swój charakter z autorytarnego na totalitarny. W szczególności wówczas gdy będą dążyły do regulacji każdego przejawu ludzkiej aktywności.

[...] rygorystyczne przestrzeganie apriorycznie określonych praw naturalnych w rękach konkretnej władzy lub społeczności przerodzić się może w skrajną tyranię ${ }^{34}$.

Do takich wniosków dochodził Karol Marks, który głosił, że prawa naturalne są „rodzajem kwiatów, którymi przyozdabiano kajdany”35. Marks stał na stanowisku, że klasa panująca wykorzystuje prawa naturalne do dominacji nie tylko na polu ekonomii i polityki, lecz także kultury. Na kulturowe uwarunkowania praw naturalnych prowadzących do autorytarnego postrzegania roli kobiety w życiu społecznym wskazują feministki. Doktryna feministyczna stoi bowiem na stanowisku, że prawa naturalne służyły przez stulecia zniewoleniu kobiet ${ }^{36}$. Klasyczne

31 J. Baszkiewicz, Wprowadzenie w problematyke konferencji, [w:] Prawo natury $w$ doktrynach polityczno-prawnych Europy, red. M. Zmierczak, Poznań 2006, s. 10.

32 Duży wkład w badania nad osobowością autorytarną mieli Erich Fromm oraz Theodor W. Adorno.

33 J. Baszkiewicz, Wprowadzenie..., s. 10.

${ }^{34} \mathrm{~K}$. Chojnicka, Zagadnienie relacji pomiędzy prawem naturalnym a prawem stanowionym. Analiza trzech możliwych ujęć tego zagadnienia w klasycznych systemach doktrynalnych, [w:] Prawo natury w doktrynach polityczno-prawnych Europy..., s. 68-69.

35 W. Bernacki, Zmienność i niezmienność prawa naturalnego, [w:] Prawo natury $w$ doktrynach polityczno-prawnych Europy..., s. 73.

36 Ibidem. 
prawa naturalne, w szczególności te o niezmiennej treści dotyczącej prokreacji, ograniczały aktywność kobiet w życiu społecznym ${ }^{37}$.

$\mathrm{W}$ koncepcjach prawnonaturalnych powiązanych $\mathrm{z}$ doktrynami religijnymi ius naturalis staje się podbudową norm prawa stanowionego $\mathrm{z}$ reguły $\mathrm{w}$ ściśle określonym zakresie. Co do zasady, normy prawnonaturalne nie dążą do szczegółowej reglamentacji kwestii związanych z gospodarką, techniką czy kulturą. Należy bowiem podkreślić, że $\mathrm{w}$ doktrynach prawa naturalnego odwołującego się do autorytetu Stwórcy istotne znaczenie będzie miało opieranie się na emocjach, stosowanie symboliki, odwoływanie się do więzów krwi czy uczuć patriotycznych (co często prowadzi do nacjonalizmu). Tak ujęte treści praw naturalnych są stałe, zmieniać się może jedynie ich forma (zgodnie z koncepcją dynamiczną praw naturalnych ukształtowaną po Soborze Watykańskim II) ${ }^{38}$. Prawo stanowione nie powinno popadać z nimi w sprzeczność.

W ciągu stuleci prawa naturalne pełniły jedną z dwóch zasadniczych funkcji: konserwatywną lub reformatorską. Ta pierwsza legitymizowała istniejący porządek prawny, druga była „korekcyjna, wzywająca do zmiany prawa pozytywnego" 39 .

Należy na koniec podkreślić, że bycie zwolennikiem prawa naturalnego nie oznacza bynajmniej uznawania natury człowieka za conditio sine qua non jego istnienia. Oprócz teorii uznających naturę jednostki ludzkiej za fundament tego prawa istnieją także takie konstrukcje, które wiążą prawo naturalne $\mathrm{z}$ idealnym rozwiązaniem kwestii społecznych oraz oceną prawa stanowionego.

Mimo wielu problemów, mnożących się nieścisłości zarówno w przedmiocie definiowania, jak i kwestii określenia statusu tej dyscypliny należy podkreślić, iż filozoficzne interpretacje prawa nie są jedynie dywagacjami czysto abstrakcyjnymi, zupełnie oderwanymi od życia, lecz często pozostają w służbie praktyki. Tę tezę doskonale ilustruje idea nieposłuszeństwa obywatelskiego, którego kamień węgielny stanowiło silne przekonanie o niezbywalnych prawach przynależnych człowiekowi, niezależnych od wszelkich aktów stanowionych, konwencji i umów ${ }^{40}$. Ponadto zgodzić się należy z Leo Straussem, iż prawa naturalne są

37 S. Benhabib, Feminism and Postmodernism. An Uneasy Alliance, [w:] Feminist Contentions. A Philosophical Exchange, red. S. Benhabib et al., New York 1995, s. 17-34; K. Ślęczka, Feminizm: ideologie i koncepcje społeczne współczesnego feminizmu, Katowice 1999; R.P. Tong, Myśl feministyczna. Wprowadzenie, Warszawa 2002; J. Mizielińska, Dekonstrukcja kobiecości, Gdańsk 2004.

38 M. Łuszczyńska, Zmierzch czy renesans idei praw naturalnych? Analiza teorii praw naturalnych jako wzorca, ,reguly i miary” prawa stanowionego, [w:] Kontynuacje i nowatorstwo w świecie współczesnych idei, red. M. Mikołajczyk, M. Śliwa, Kraków 2008, s. 31-42.

39 J. Baszkiewicz, Wprowadzenie..., s. 17.

40 Najlepszym przykładem jest mający miejsce w latach 50. ubiegłego stulecia w Stanach Zjednoczonych protest przeciwko sankcjonowanej prawnie segregacji rasowej, na którego czele stał M.L. King, czy polityka biernego oporu stosowana przez Hindusów w latach 40. XX w. pod duchowym przywództwem M. Gandhiego, która doprowadziła do przyznania im przez Anglików prawa do własnego państwa. Szerzej o kwestii nieposłuszeństwa obywatelskiego zob. J. Gałkowski, A. Szutta, Prawo naturalne a niepostuszeństwo obywatelskie, [w:] Powrót do prawa ponadustawowego..., 
w pełni ahistoryczne, historie mają jedynie odnoszące się do nich teorie ${ }^{41}$. Odnotować jednak należy, że największy wkład w badania nad problematyką prawa naturalnego wniosły państwa, które zrzuciły z siebie jarzmo faszyzmu, czyli Niemcy, Włochy i Austria ${ }^{42}$.

\section{Bibliografia}

Baszkiewicz J., Myśl polityczna wieków średnich, Warszawa 1970.

Baszkiewicz J., Wprowadzenie $w$ problematyke konferencji, [w:] Prawo natury $w$ doktrynach polityczno-prawnych Europy, red. M. Zmierczak, Poznań 2006.

Benhabib S., Feminism and Postmodernism: An Uneasy Alliance, [w:] Feminist Contentions. A Philosophical Exchange, red. S. Benhabib et al., New York 1995.

Bensch T., Ksztaltowanie się pogladów na stosunek prawa naturalnego do pozytywnego, „Prąd” 1937, $\mathrm{nr} 33$.

Bernacki W., Zmienność i niezmienność prawa naturalnego, [w:] Prawo natury $w$ doktrynach polityczno-prawnych Europy, red. M. Zmierczak, Poznań 2006.

Bobbio N., Giusnaturalismo e positivismo giurdico, Milano 1965.

Borucka-Arctowa M., Prawo natury jako ideologia antyfeudalna, Warszawa 1957.

Borucka-Arctowa M., Wspótczesna koncepcja praw człowieka, [w:] Księga pamiatkowa ku czci Konstantego Grzybowskiego, Kraków 1971.

Chojnicka K., Zagadnienie relacji pomiędzy prawem naturalnym a prawem stanowionym. Analiza trzech możliwych ujęć tego zagadnienia w klasycznych systemach doktrynalnych, [w:] Prawo natury w doktrynach polityczno-prawnych Europy, red. M. Zmierczak, Poznań 2006.

Działocha K., Gromski W., Niepozytywistyczna koncepcja państwa prawnego a Trybunat Konstytucyjny, „Państwo i Prawo” 1995, nr 3.

Falandysz L., Likwidacja filozofii prawa, [w:] Nauka a polityka. Dziwne losy filozofii prawa, red. M. Szyszkowska, Warszawa 2001.

Forycki R., Kilka uwag o prawie natury, [w:] Powrót do prawa ponadustawowego, red. M. Szyszkowska, Warszawa 1999.

Gałkowski J., Szutta A., Prawo naturalne a niepostuszeństwo obywatelskie, [w:] Powrót do prawa ponadustawowego, red. M. Szyszkowska, Warszawa 1999.

Izydor z Sewili św., Etymologiae, [Augsburg] 1792.

Jarra E., Człowiek a władza, Londyn 1948.

s. 138-157. Por. W. Lang, J. Wróblewski, Sprawiedliwość społeczna i niepostuszeństwo obywatelskie $w$ doktrynie politycznej USA, Warszawa 1984, s. 212-269.

41 L. Strauss, Prawo naturalne w świetle historii, Warszawa 1969.

42 W porównaniu z Włochami dorobek obszaru niemieckojęzycznego jest zdecydowanie bogatszy, zarówno pod względem zakresu poruszanej problematyki, jak i kwestii podejścia do owej tematyki. Por. H. Waśkiewicz, „Drugie odrodzenie” prawa naturalnego, „Roczniki Filozoficzne” 2, 1962, s. 115-151. Odrodzenie zainteresowań prawem natury po II wojnie światowej objęło swoim zasięgiem nie tylko państwa europejskie (RFN, Belgię, Francję, Włochy, Austrię, Hiszpanię i Anglię), lecz także państwa pozaeuropejskie (oprócz wymienionych już Stanów Zjednoczonych, również Japonię i część państw południowoamerykańskich). Zob. K. Jonca, Czy zmierzch doktryny prawa natury? Niemieckie spory wokót prawa natury po II wojnie światowej, [w:] Doktryny polityczne i prawne u progu XXI wieku..., s. 384. 
Jonca K., Czy zmierzch doktryny prawa natury? Niemieckie spory wokót prawa natury po II wojnie światowej, [w:] Doktryny polityczne i prawne u progu XXI wieku, red. M. Maciejewski, M. Marszał, Wrocław 2002.

Kalinowski J., Teoria reguły społecznej i reguly prawnej Leona Duguita, Lublin 1949.

Kantorowicz E.H., The King's Two Bodies. A Study in Medieval Political Theory, Princeton 1957.

Kelly J.M., Historia zachodniej teorii prawa, Kraków 2006.

Kość A., Filozoficzne podstawy prawa japońskiego w perspektywie historycznej, Lublin 2001.

Lang W., Wróblewski J., Sprawiedliwość społeczna i niepostuszeństwo obywatelskie $w$ doktrynie politycznej USA, Warszawa 1984.

Łuszczyńska M., Zmierzch czy renesans idei praw naturalnych? Analiza teorii praw naturalnych jako wzorca, ,reguty i miary” prawa stanowionego, [w:] Kontynuacje i nowatorstwo w świecie współczesnych idei, red. M. Mikołajczyk, M. Śliwa, Kraków 2008.

Łuszczyńska M., Łuszczyński A., Positivisation of the natural law in the contents of constitutions of European countries, [w:] Positive Law in Contemporary Legal Systems, red. B. Lepieszko, D. Walencik, Brest 2009.

Małajny R., Regulacja kwestii konfesyjnych w Konstytucji III RP (refleksje krytyczne), [w:] Ze sztandarem prawa przez świat, red. R. Tokarczyk, K. Motyka, Kraków 2002.

Mizielińska J., Dekonstrukcja kobiecości, Gdańsk 2004.

Morawski L., Spór o pojęcie państwa prawnego, „Państwo i Prawo” 1994, nr 7-8.

Opałek K., Wróblewski J., Prawo. Metodologia, filozofia, teoria prawa, Warszawa 1991.

Pieniążek A., Polityka tworzenia prawa w okresie przemian polityczno-ustrojowych, [w:] $W$ kręgu problematyki władzy, państwa i prawa, red. J. Malarczyk, Lublin 1996.

Roth H., W sprawie koncepcji prawa i praworzadności, „Państwo i Prawo” 1994, nr 7-8.

Sadowski M., Godność człowieka i dobro wspólne w papieskim nauczaniu społecznym, Wrocław 2010.

Sadowski M., Ze studiów nad papieską koncepcja godności człowieka (1981-1991), [w:] Doktryny polityczne i prawne u progu XXI wieku, red. M. Maciejewski, M. Marszał, Wrocław 2002.

Skrzydło W., Konstytucja Rzeczypospolitej Polskiej. Komentarz, Kraków 2000.

Stachewicz K., W poszukiwaniu podstaw moralności. Tomistyczna etyka prawa naturalnego a etyka wartości Dietricha von Hildebranda, Kraków 2001.

Stefaniuk M., Obowiazki czlowieka i obywatela w projektach Konstytucji RP z dnia 2 kwietnia 1997 r. na tle polskich konstytucji ustrojowych $w X X$ w, [w:] Ze sztandarem prawa przez świat, red. R. Tokarczyk, K. Motyka, Kraków 2002.

Strauss L., Prawo naturalne w świetle historii, Warszawa 1969.

Szyszkowska M., Dociekania nad prawem natury, czyli o potrzebach człowieka, Warszawa 1972.

Szyszkowska M., Filozofia prawa i filozofia czlowieka, Warszawa 1989.

Ślęczka K., Feminizm: ideologie i koncepcje społeczne współczesnego feminizmu, Katowice 1999.

Ślipko T., Problem stabilności prawa naturalnego, [w:] Powrót do prawa ponadustawowego, red. M. Szyszkowska, Warszawa 1999.

Tanalski D., Wartości konstytucji i konkordatu, [w:] Powrót do prawa ponadustawowego, red. M. Szyszkowska, Warszawa 1999.

Tong R.P., Myśl feministyczna. Wprowadzenie, Warszawa 2002.

Urmanowicz W., U źródet nauki o zasięgu prawa naturalnego, „Collectanea Theologica” 26, 1955, nr 4.

Waśkiewicz H., „Drugie odrodzenie” prawa naturalnego, „Roczniki Filozoficzne” 2, 1962.

Waśkiewicz H., Historia teorii prawa naturalnego, „Roczniki Filozoficzne” 2, 1962.

Waśkiewicz H., Powszechność prawa naturalnego, „Studia Philosophiae Christianae ATK” 1970, nr 6.

Winczorek P., Problem prawa naturalnego w dyskusjach konstytucyjnych, [w:] Powrót do prawa ponadustawowego, red. M. Szyszkowska, Warszawa 1999.

Studia nad Autorytaryzmem i Totalitaryzmem 39, nr 2, 2017

(C) for this edition by CNS 
Wróblewski J., Wpływ prawa natury na prawo pozytywne, „ZN UŁ. Nauki Humanistyczno-Społeczne" 1968, nr 1.

Wyszyński S., Co duszpasterz może zrobić dla urzeczywistnienia ustroju korporacyjnego, [w:] A. Roszkowski, Korporacjonizm, Lublin 1939.

Zachariasz A.L., Prawo naturalne jako prawo kultury, [w:] Powrót do prawa ponadustawowego, red. M. Szyszkowska, Warszawa 1999.

Zmierczak M., Pozytywizm prawniczy a prawnicy i prawo w Trzeciej Rzeszy — powojenna dyskusja niemieckich historyków i teoretyków prawa o przyczynach upadku prawa w czasach nazizmu, „Studia nad Faszyzmem i Zbrodniami Hitlerowskimi” 24, 2001.

Zoll A., Związanie sędziego ustawa, [w:] Konstytucja i gwarancje jej przestrzegania. Księga pamiatkowa ku czci prof. Janiny Zakrzewskiej, red. J. Trzciński, A. Jankiewicz, Warszawa 1996.

\section{AUTHORITARIAN LAWS OF NATURE? SEVERAL NOTES ON THE NEGATIVE POTENTIAL OF POSITIVE CONCEPTS}

\section{Summary}

The article presents authors' reflection upon the problem of the law of nature. In the literature on the subject, there is a dominant opinion that the natural law is a type of a matrix, which should be duplicated by the legislator in order to prevent unfair laws. Following the Latin maxim: "Lex iniusta non est lex" ("Unfair law is not a law"), legislator must take into account all non-specified norms of the higher order. According to the authors of this article, in the modern times the natural law rationalism is rather apparent, and its religious foundations will not necessarily be accepted in the culturally plural [multicultural?] society.

Keywords: law of nature, authority, axiology.

Małgorzata Łuszczyńska

m.luszczynska@poczta.umcs.lublin.pl

Artur Łuszczyński

aluszczynski@ur.edu.pl 